mental delivery because of fetal distress, but none of the mothers in this group showed any consistent or significant changes in blood pressure following injection of pethidine. In the pentazocine group five patients had instrumental deliveries-two because of a delay in the second stage, one because of an increase in systolic blood pressure, one because of fetal distress, and one because of deep transverse arrest. Two patients who received pentazocine had a sustained increase in blood pressure. One of these showed a rise of more than $10 \mathrm{~mm}$. $\mathrm{Hg}$ after the first or second injections but a sustained increase of $20-25 \mathrm{~mm}$. $\mathrm{Hg}$ after the third injection. This patient was one of the older primigravida who had hypertension during the later stages of pregnancy.

\section{Discussion}

The results of this study indicate that the two drugs have similar analgesic and sedative properties. Complaints of sideeffects occurred more frequently after pethidine, though the difference between the drugs in this respect was not statistically significant $(P=0.05)$. It is, however, interesting to note that no patient given pentazocine complained of any sideeffects after the second or third injection, and emetic sequelae were less frequent with pentazocine than with pethidine after the first injection. These results agree with those of other workers. With doses comparable to those used in this trial, a study performed in Reading reported an incidence of nausea and vomiting after pethidine which was three times greater than that following pentazocine (County Borough of Reading Midwifery Service, 1969). In addition to finding no difference in analgesic efficacy between the two trial drugs, we were unable to establish a difference in the duration of action as shown by the demand for further analgesia.

Only two infants required resuscitation, and both had factors which complicated the delivery. The Apgar scores show slightly better results for the pentazocine group than for the pethidine group after the final assessment, but up to this time there is little difference between the two drugs reflected in the scoring. The scores with both drugs were not low, and these results agree with those of Massinger and Lazaridis (1968) and of the County Borough of Reading Midwifery Ser- $\stackrel{\Phi}{\circ}$ vice (1969). Though babies born to mothers given pentazocine $c$. had slightly higher Apgar scores after 10 minutes than babies $\ddot{\Rightarrow}$ born to mothers given pethidine, the number of infants invol- $\stackrel{\rho}{\stackrel{9}{ }}$ ved is insufficient to confirm the finding of Gonzales Munoz? (1966) described above.

In conclusion, this trial has shown that pentazocine is a $\frac{\bar{\omega}}{\vec{D}}$ suitable parenteral analgesic in labour and can safely be used $\stackrel{\mathbb{Q}}{\Omega}$ in circumstances where pethidine would otherwise be the drug of choice.

We wish to thank the labour ward staff at Ross Hospital and $\vec{\omega}$ the Royal Maternity Hospital; the Sterling Winthrop Research of Division for the matching supplies of drugs; and $\mathrm{Mr}$. T. S. Muir, of that company, for his help and encouragement. The statistical analysis was performed by Mr. N. Jackman.

\section{REFERENCES}

Beckett, A. H., and Taylor, J. F. (1967). fournal of Pharmacy and Pharmacology, 19, Suppl. p. $50 \mathrm{~S}$.

Brandstater, B. (1966). Acta Anaesthesiologica Scandinavica, Suppl. No. N

25, p. 345 .
County Borough of Reading Midwifery Service (1969). Midwives Chron-C icle and Nursing Notes, 82, 400

Crawford, J. S. (1966). American Fournal of Obstetrics and Gynecology,

96, 382. S. (1966). American Fournal of Obstetrics and Gynecology, त

Duncan, S. L. B., Ginsberg, J., and Morris, N. F. (1969). American $\overrightarrow{0}$ Fournal of Obstetrics and Gynecology, 105, 197.

Filler, W. W., jun., and Filler, N. W. (1966). Obstetrics and Gyneco-? $\log y, 28,224$.

Gonzales Munoz, E. (1966). Bibliografia Médica International, 26, Оิ (October 1966).

Massinger, H., and Lazaridis, S. T. (1968). Gynaecologia, 163, 40. Moore, J., Carson, M., and Ball, H. (1970). Midwives Chronicle and
Nursing Notes, 83, 12 .

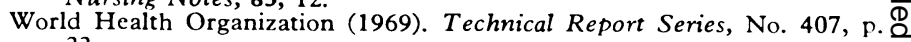
23.

\title{
Mental Deterioration in Epilepsy due to Folate Deficiency
}

\author{
C. NEUBAUER,* M.D.
}

\begin{abstract}
ummary: Folate deficiency in 50 epileptic children $\checkmark$ aged 5 to 18 years was treated with a combination of folic acid and vitamin $B_{12}$. Improvement in mental condition occurred from five to eight weeks after beginning treatment in some of the younger children; no change was noticed, however, in 31. Similarly, in 19 children fits became less frequent and less severe. It is recommended that both folic acid and vitamin $B_{12}$ should be given as soon as a patient is started on anticonvulsant drugs to prevent mental deterioration.
\end{abstract}

\section{Introduction}

Mental deterioration is the mosi serious aspect of epilepsy. The deterioration is caused by reditary mental defect in some cases and by brain damage in others. Anticonvulsant drugs, however, can produce adverse el ects on cerebration in any epileptic patient. It is common experience to see patients under treatment becoming slower, their span of attention becoming shorter, and their manual dexterity deteriorating. Even medically untrained people-for example, teachersnotice a change in performance of epileptic children at school.

${ }^{*}$ Consultant, Prudhoe and Monkton Hospital, Northumberland.
They find the pupil has poor co-ordination, appears unable toô perform many of the tasks which previously he could do well, and is no longer able to take part in school activities.

The side-effects of treatment with anticonvulsant drugs N which first attracted the attention of clinicians were anaemia and vitamin $\mathrm{B}_{12}$ deficiency. These complications were investigated in the early 1950s, and reports of folate deficiency in non-anaemic epileptics treated with drugs followed (Hawkins and Meynell, 1958; Malpas, Spray, and Witts, 1966; Reynolds, $\sigma$ 1967a). Malpas and his co-workers studied 48 patients receiv-? ing anticonvulsant drugs at Chalfont Colony. Of these, 11 had serum folate levels of $2.1 \mathrm{ng} . / \mathrm{ml}$. or less, and two low vitamin $\mathbf{B}_{12}$ levels. The vitamin $\mathbf{B}_{12}$ content of the patients' diet was? normal. Moreover, it was confirmed that the patients suffering from folate deficiency had no inherent defect of folate metab- $\frac{\mathbb{D}}{D}$ olism. In five cases epilepsy developed after head injury, while $\frac{\rho}{\mathbb{1}}$ four patients developed macrocytosis and a low folate level $\varrho$ during treatment. To prove that the drugs were the cause of the haematological changes they were stopped, and the blood 8 picture then returned to normal. When the drugs were? restarted the changes recurred.

In an investigation of the effect of folic acid on the mental state and frequency of fits of epileptics treated with anticonvulsants, improvement in speech, action, alertness, and concentration were found (Reynolds, 1967b). The patients became more sociable and the quality of their work improved. Three 
out of five unemployed patients went back to work; in 13 out of 26 patients, however, the severity of the fits increased, and administration of folic acid had to be stopped in nine of them. Vitamin $B_{12}$ was also given in six cases some months later either because of falling vitamin- $B_{12}$ levels or because of a poor response mentally.

\section{Patients and Methods}

The present investigation was carried out on 50 children and adolescents ( 32 boys and 18 girls). One was under 5 years of age, 26 were 6 to 15 years, and 23 were 16 to 18 years. All 50 patients had been treated with anticonvulsant drugs for several years (Table I).

TABLE I.-Duration of Treatment

\begin{tabular}{rrr|r|r|r|r|r|r|r|r|r|r|r|}
\hline $\begin{array}{l}\text { No. of years } \\
\text { No. of cases }\end{array}$ & $\ldots$ & $\ldots$ & 1 & 2 & 3 & 4 & 5 & 6 & 7 & 8 & 9 & 10 & 11 \\
\hline
\end{tabular}

The serum folate levels were assessed by microbiological assay with Lactobacillus casei as the test organism by the method of Waters and Mollins. The normal range is from 5.9 to $21 \mathrm{ng} . / \mathrm{ml}$. (Wells and Casey, 1967), while the range accepted in Newcastle is from 3 to $20 \mathrm{ng} . / \mathrm{ml}$. The normal range of serum $B_{12}$ is from 160 to $925 \mathrm{pg} . / \mathrm{ml}$. determined by microbiological assay with $L$. leichmannii as the test organism.

Therapy.-We were guided in our approach to the treatment of folate deficiency in epilepsy by experience gained in other fields of medicine. In our study folic acid and vitamin $B_{12}$ were administered simultaneously. The dose of folic acid was $15 \mathrm{mg}$. a day in patients with very low serum folate levels - of less than $2 \mathrm{ng} . / \mathrm{ml}$.- -but $10 \mathrm{mg}$. a day was sufficient for patients with folate levels of 3 to $4 \mathrm{ng}$. $/ \mathrm{ml}$. After four to six weeks the folate levels returned to normal and the dose was reduced; eventually the patients were put on a weekly maintenance dose of $10 \mathrm{mg}$. of folic acid. As this produced too high folate levels, however-over $30 \mathrm{ng} . / \mathrm{ml}$. - we are now giving $5 \mathrm{mg}$. of folic acid per week, and this dosage keeps the folate level within normal limits. Vitamin $\mathbf{B}_{12}$ (cyanocobalamin) was given according to the serum $\mathrm{B}_{12}$ level. If the level was very low the weekly dose was $1,000 \mu \mathrm{g}$. After four to eight weeks this was reduced by half. The maintenance dose was $250 \mu \mathrm{g}$. per month.

\section{Results}

\section{Anticonvulsant Drugs}

The effects of drugs and drug combinations on the serum folate are summarized in Table II. The lowest readings were caused by phenytoin and primidone, either given alone or in various combinations.

We also examined the cerebrospinal fluid in some special cases, the relation between serum and cerebrospinal fluid folate levels being shown in Table III. In one patient (Case 64), the concentration of folic acid was more than five times as high in the cerebrospinal fluid as in the serum, and in Case 67 it was more than nine times as high, but still well below normal. Patients with severe retardation had lower folate levels; one patient (Case 67), with an almost normal cerebrospinal fluid level, was mentally quite alert. Patients with dementia, psychosis, depression or retardation, or both, and behaviour disorders had significantly lower cerebrospinal fluid folate levels than those who were mentally normal (Reynolds, Preece, and Chanarin, 1969). There was no case of macrocytic anaemia in the present series.

The serum $B_{12}$ levels are shown in Table IV. In one patient

\begin{tabular}{|c|c|c|c|c|}
\hline \multirow{2}{*}{ Drug } & \multicolumn{4}{|c|}{ Serum Folate Level (ng./ml.) } \\
\hline & 0.6 to 1.9 & 2 to 2.9 & 3 to 3.9 & 4 to 4.9 \\
\hline $\begin{array}{l}\text { Phenytoin and primidone, single } \\
\text { or combined } \\
\text { Sulthiame and phenobarbitone, } \\
\text { single or combined .. }\end{array}$ & $\begin{array}{r}10 \\
1\end{array}$ & $\begin{array}{r}13 \\
4\end{array}$ & $\begin{array}{l}5 \\
7\end{array}$ & $\begin{array}{l}3 \\
7\end{array}$ \\
\hline
\end{tabular}

TABLE III

\begin{tabular}{|c|c|c|c|}
\hline \multirow{2}{*}{ Case No. } & \multicolumn{2}{|c|}{ Folate Levels (ng./ml.) } & \multirow{2}{*}{ Remarks } \\
\hline & Serum & $\begin{array}{l}\text { Cerebrospinal } \\
\text { Fluid }\end{array}$ & \\
\hline & 14 & 40 & \multirow{2}{*}{$\begin{array}{l}\text { Under treatment with folic acid } \\
\text { and vitamin } B_{1 x}\end{array}$} \\
\hline $\begin{array}{l}15 \\
48 \\
54 \\
63 \\
64 \\
67\end{array}$ & $\begin{array}{l}2.4 \\
1.3 \\
2 \cdot 2 \\
3.8 \\
1.6 \\
1.9\end{array}$ & $\begin{array}{r}4.2 \\
1.3 \\
13.1 \\
11.6 \\
9.1 \\
18.2\end{array}$ & \\
\hline \multicolumn{4}{|c|}{ TABLE IV } \\
\hline
\end{tabular}

\begin{tabular}{|c|c|c|c|c|c|c|}
\hline & & \multicolumn{4}{|c|}{ Serum $B_{12}$ Levels in pg. $/ \mathrm{ml}$. } & \multirow[b]{2}{*}{$601-700$} \\
\hline & 160 & $161-200$ & $201-300$ & $301-500$ & $501-600$ & \\
\hline No. of cases & 11 & 1 & 13 & 18 & 3 & 4 \\
\hline
\end{tabular}

TABLE V.-Duration of Treatment with Folic Acid and Vitamin $B_{12}$ 3efore Improvement

\begin{tabular}{ll|l|l|l|l|l|r|r|r|r|r|r|r|r|r}
\hline $\begin{array}{l}\text { No. of weeks } \\
\text { No. of cases }\end{array}$. & 5 & 6 & 7 & 8 & 9 & 10 & 11 & 12 & 13 & 14 & 15 & 21 & 24 & 26 \\
1
\end{tabular}

the $B_{1:}$ level went up from 205 to $740 \mathrm{pg} . / \mathrm{ml}$. in six weeks. When the dose is reduced too early, however, relapse may occur. One patient, a boy of 11 , had a serum folate level of $2.5 \mathrm{ng} . / \mathrm{ml}$. and a $B_{12}$ level of $502 \mathrm{pg} . / \mathrm{ml}$. He had catatonic symptoms, leaving his arm in any position in which it was placed, and would sit holding a piece of bread rather than put it into his mouth. Nevertheless, his mental condition improved with treatment. When the doses of folic acid and vitamin $B_{12}$ were reduced, however, he became less lively and had to be put back on his previous dose. We also noticed that some patients became less alert and that the fits became as frequent as before treatment when they were put on a maintenance dose. In such cases the patients had to be put back on the previous dose. The maintenance dose has to be continued as long as anticonvulsants are given.

\section{Fits}

The attempts to treat folate deficiency in epileptic patients with folic acid were successful in so far as there was an improvement in the mental state in some patients. Nevertheless the treatment failed in others, the fits becoming more frequent and more severe; in some cases treatment had to be stopped. We therefore agree that "treatment with folic acid although it may help the general condition of the patient may make the convulsions more frequent" (Gibberd, 1969). One result that emerged from the present investigation was that the fits did not increase in number or in severity when folic acid and vitamin $B_{12}$ were given together. In fact, the fits not only became less frequent but also less severe in many cases. There was no change, however, in the incidence and severity of fits in 30 of the 50 patients. In 16 cases the fits became less frequent, while in four they stopped for several months; in one case a severe fit occurred after two months, in another a series of very mild fits occurred after seven months, while in another there was a transitory increase after two months, which subsided without change of treatment after one week. In no instance did the treatment have to be discontinued. 


\section{Mental Condition}

All patients were treated with both folic acid and vitamin $B_{12}$ from the start of the study. The duration of treatment before improvement could be noticed varied from 5 to 26 weeks (Table V). Improvement was noticed from five to eight weeks after beginning treatment in younger children, but it took much longer in adolescents. Some children became brighter and livelier (nine cases), some more energetic and active (five cases), more relaxed and happier (three cases), more interested but also more aggressive (one case), more cheerful (one case), more approachable and affectionate (one case), and some started to talk again (four cases). Similarly, head banging was stopped in one child; three stopped crying, shouting, and keeping other patients awake; appetite improved in two; two tried to walk; one no longer lay in a chair all day but started walking, sitting, and reading comics; in one child incontinence of faeces and smearing stopped; two started performing small tasks and going shopping; and three went back to school or training centre. Some improvement was noticed in 22 patients, but no change occurred in the other 28. Three children relapsed after initial improvement-one after two months, another after three months, and the third after six months-and reverted to their former mental state. Among those who did not show any improvement 12 had fewer and less severe fits.

\section{Discussion and Conclusions}

All anticonvulsant drugs eventually lower the serum folate level; the cause of this relation between anticonvulsants and folic acid metabolism has so far not been elucidated (Baugh and Krumdieck, 1969). Furthermore, there is an important relation between the level of folate in the serum and in the cerebrospinal fluid. It is known that the level in the latter is about three times as high as that in the former (Herbert and Zalusky, 1961), and that the level in the cerebrospinal fluid reflects the folate concentration in the central nervous system much better than the serum folate level. The range of the folate level in the cerebrospinal fluid is 12.6 to $67 \mathrm{ng} . / \mathrm{ml}$., the rather high concentration of folic acid in the cerebrospinal fluid obviously being important for the normal functioning of the brain. Linus Pauling (1969) stated: "Folic acid, thiamine, pyridoxine and other substances (zinc ion, magnesium ion, tryptophan, etc.) are present at rather high concentration in the brain and nerve tissue and play an essential role in the functioning of these tissues. . . The functioning of the brain and nervous tissue is more sensitively dependent on the rate of chemical reactions than the functioning of other organs and tissues."

The level of serum $\mathbf{B}_{12}$ is as important as the serum folate level, as is the balance between folic acid and vitamin $B_{1:}$ in both the serum and the cerebrospinal fluid. In pernicious anaemia a genetic defect leads to deficiency of the intrinsic factor in the gastric juice and consequently to decreased $B_{1:}$ in the blood. If such a patient is given folic acid a further fall in serum $\mathbf{B}_{12}$ will follow, leading sooner or later to subacute degeneration of the cord. How and why this reaction between these two drugs takes place is unknown. When folic acid is given by itself to an epileptic patient it depresses the $B_{1}$ level.

The case of a woman aged 32 with a serum folate level of $2.4 \mathrm{ng} . / \mathrm{ml}$. and a $\mathrm{B}_{12}$ level of $284 \mathrm{pg} . / \mathrm{ml}$. has been recorded. She was given $15 \mathrm{mg}$. of folic acid a day. A year later the folic acid level was more than $40 \mathrm{ng} . / \mathrm{ml}$. while the $B_{12}$ level had fallen to $52 \mathrm{pg} . / \mathrm{ml}$. Hunter, Barnes, and Matthews (1969) found a striking fall in the serum $B_{12}$ level to about half after three months of treatment with folic acid.

Folic acid has been known to precipitate epileptic fits (Chanarin, Laidlaw, Loughbridge, and Mollin, 1960). Reynolds (1967b) also observed that the frequency and severity of the fits increased; in some cases the treatment had to be stopped. Vitamin $B_{12}$ was also given in six cases some months after the folic acid because of falling $B_{12}$ levels. This led to improvement in the mental state in some cases, but to further aggravation of fits in three others.

In an assessment of this report the fact that all the children had been treated for epilepsy for years has to be borne in mind. For this reason all the children had obviously been suffering from folate deficiency for a long time, since the deficiency develops within a few weeks or months of onset of treatment. When a patient's condition has been slowly but steadily deteriorating even a slight improvement in his mental condition is welcome. If a patient becomes livelier, looks happier, starts to move about, or becomes approachable it indicates some progress. The nursing staff appreciated it very much when children stopped crying all the time and became clean in their habits. The best results are shown when the child can go back to school or start work, but these cases are few. As in other fields of medicine prevention would be better than : reatment, and this should be possible with a small amount of folic acid-5 mg. per week-and vitamin $B_{12}$ $250 \mu \mathrm{g}$. once a month. These drugs should be given as soon as a patient is treated with anticonvulsant drugs.

I am grateful to the Biochemical Assay Laboratory, Pathological Institute, Newcastle General Hospital, for the help given to me in carrying out this investigation.

\section{REFERENCES}

Baugh, C. M., and Krumdieck, C. L. (1969). Laniet, 2, 519.

Chanarin, I, Laidlaw, J, Loughbridge, L. W., and Mollin, D. L. (1960). British Medical fournal, 1, 1099.

Gibberd, F. B. (1969). British Medical fournal, 4, 281

Hawkins, C. F., and Meynell, M. J. (1958). Quarterly fournal of Medicine, 27, 45

Herbert, V., and Zalusky, R. (1961). Federation Proceedings, 20, 453.

Hunter, R., Barnes, J., and Matthews, D. M. (1969). Lancet, 2, 666.

Malpas, J. S., Spray, G. H., and Witts, L. J. (1966). British Medical fournal, 1, 955 .

Pauling, L. (1968). Science, 160, 265.

Reynolds, E. H. (1967a). British fournal of Psychiatry, 113, 911.

Reynolds, E. H. (1967b). Lancet, 1, 1086.

Reynolds, E. H., Preece, J., and Chanarin, I. (1969). Lancet, 1, 1265.

Wells, D. G., and Casey, H. J. (1967). British Medical fournal, 3, 834 